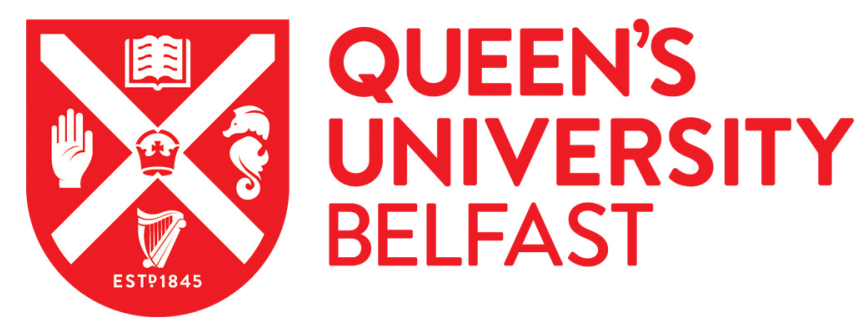

\title{
Mammoths inside the Alps during the last glacial period: Radiocarbon constraints from Austria and palaeoenvironmental implications
}

Spötl, C., Reimer, P. J., \& Göhlich, U. B. (2018). Mammoths inside the Alps during the last glacial period: Radiocarbon constraints from Austria and palaeoenvironmental implications. Quaternary Science Reviews, 190, 11-19. https://doi.org/10.1016/j.quascirev.2018.04.020

Published in:

Quaternary Science Reviews

Document Version:

Peer reviewed version

Queen's University Belfast - Research Portal:

Link to publication record in Queen's University Belfast Research Portal

Publisher rights

Copyright 2018 Elsevier

This manuscript is distributed under a Creative Commons Attribution-NonCommercial-NoDerivs License

(https://creativecommons.org/licenses/by-nc-nd/4.0/), which permits distribution and reproduction for non-commercial purposes, provided the author and source are cited.

\section{General rights}

Copyright for the publications made accessible via the Queen's University Belfast Research Portal is retained by the author(s) and / or other copyright owners and it is a condition of accessing these publications that users recognise and abide by the legal requirements associated with these rights.

Take down policy

The Research Portal is Queen's institutional repository that provides access to Queen's research output. Every effort has been made to ensure that content in the Research Portal does not infringe any person's rights, or applicable UK laws. If you discover content in the Research Portal that you believe breaches copyright or violates any law, please contact openaccess@qub.ac.uk. 
Mammoths inside the Alps during the last glacial period: radiocarbon constraints from Austria and palaeoenvironmental implications

8

${ }^{2}$ Centre for Climate, the Environment and Chronology (14CHRONO), School of Natural and Built Environment, Queen's University Belfast, Belfast BT7 1NN, UK ${ }^{3}$ Natural History Museum Vienna, Geological-Palaeontological Department,

Burgring 7, 1010 Vienna, Austria

17 


\section{$1 \quad$ Abstract}

This study examines remains of the woolly mammoth (Mammuthus primigenius) found inside the Austrian Alps, an area occupied by an extensive ice-stream network during the Last Glacial Maximum. The data demonstrate that these cold steppe-adapted animals locally migrated several tens of kilometers into alpine valleys. Radiocarbon analyses constrain the age of these fossils to the first half of Marine Isotope Stage 3, documenting ice-free conditions in major valleys at that time.

We also provide a list of all traceable Austrian sites of Mammuthus primigenius, totaling about 230 localities, compiled through 15 museums and collections in Austria. The vast majority of these findings are from the corridors of the Danube and Mur rivers and their tributaries and the adjacent loess-covered foreland of the Alps, areas that were never icecovered during Pleistocene glaciations.

\section{Introduction}

The woolly mammoth (Mammuthus primigenius) was the most prominent member of the Upper Pleistocene megafauna in the middle and northern latitudes of the Northern Hemisphere (Markova et al., 2010; Lister \& Bahn, 2015). This large herbivorous mammal was well adapted to the cold tundra-steppe ecosystem that existed in northern Eurasia and between the Scandinavian and the Alpine ice sheets during the last glacial period. The distribution of the woolly mammoth (Kahlke, 2015, Puzachenko et al., 2017), its evolution and genetics (Lister \& Sher, 2001, 2015; Barnes et al., 2007; Miller et al., 2008; Palkopoulou et al., 2013), ecology and diet (Tütken et al., 2007; Willerslev et al., 2014; SchwartzNarbonne et al., 2015; Boeskorov et al., 2016), as well as the dynamics of its extinction (Stuart et al., 2004; Stuart, 2005; Kuzmin, 2010; Cooper et al., 2015) have been extensively studied. 
Mammoth teeth and bones are among the most commonly found macrofossil remains of the last glacial period. They constitute an important palaeoenvironmental archive and can be dated back to about $50 \mathrm{ka} \mathrm{BP}$ using radiocarbon. For example, mammoth fossils allow to trace the migration of the southern margin of the Scandinavian ice sheet during the second half of the last glacial cycle, with rare findings almost up to the Arctic Circle during some intervals of Marine Isotope Stage (MIS) 3 - which lasted from about 60 to $30 \mathrm{ka}$ - and a progressive restriction towards lower latitudes subsequent to about $30 \mathrm{ka}$ (Ukkonen et al., 2011), reflecting the expansion of the ice sheet.

Numerous mammoth discoveries were made in the northern, eastern and western - and to a lesser extent in the southern - forelands of the European Alps. During glacial periods, this $1200 \mathrm{~km}$-long mountain range was occupied by an ice-stream network whose temporal evolution mimicked that of the Scandinavian counterpart, e.g. reduced and probably highly variable glacier sizes during MIS 3, followed by a maximum ice extent around $25 \mathrm{ka}$, when large piedmont glaciers advanced onto the Alpine foreland (e.g., Ivy-Ochs et al., 2008; Heiri et al., 2014; Monegato et al., 2017). In the northern foreland of the Western Alps mammoth remains were found in proglacial gravel beyond the outermost ice margin of the MIS 2 (Last Glacial Maximum, LGM) and also up to a few tens of kilometres inside of this margin (Furrer, 2005, 2014). This suggests that mammoths followed the waxing and waning of the LGM ice margin. Data from the the Eastern Alps (they comprise the central and western part of Austria and the southernmost part of Bavaria, Germany) reveal an interesting difference in the distribution of mammoth remains compared to the Western Alps of Switzerland: Although fossils are known up to some $40 \mathrm{~km}$ inside the LGM ice margin in northern Switzerland, there is no evidence that this mammal migrated into the west alpine valleys during the last glacial period, e.g. the Rhone or the Aare valleys. In contrast, there is clear evidence that mammoths entered the valleys of the Eastern Alps during that time (e.g., Tichy, 1989; Patzelt, 2014). The aim of this study is to address this apparent discrepancy by examining and dating all available 
mammoth specimens from the western (mountainous) part of Austria. We show that mammoths were indeed present in major inneralpine valleys during MIS 3 and discuss palaeoenvironmental and palaeoclimatic implications.

\section{Inneralpine mammoth sites}

Figure 1 provides an overview of all mammoth remains found so far in Austria including findings close to the German-Austrian border (e.g., Ebers, 1960; Dehm, 1982; Ziegler, 1994). A complete table of all currently known Austrian sites (about 230) is provided in the electronic supplement. The maps reveals the highest density of mammoth remains outside the formerly glaciated part of the Alps, i.e. along the corridor of the river Danube between the foothills of the Alps and the Bohemian Massif in the north, in the northern part of Lower Austria, in the Vienna Basin and along the Mur Valley in Styria (Fig. 1). The density of findings rapidly decreases towards the west of the meridian of Linz. Even when taking perialpine findings in southern Bavaria into account the abundance of findings is conspicuously smaller than along the northern margin of the Western Alps (Döppes \& Rabeder, 1997; Furrer, 2005, 2014; Göhlich, 2015). Only few reports of mammoth fossils exist from the southern alpine foreland (Gleirscher \& Pacher, 2005; Mussi \& Villa, 2008; Braun \& Palombo, 2012).

Essentially all findings in the inneralpine region were made decades ago and only very few new discoveries have been reported in the last few years.

Mostly isolated teeth (tusks and less abundantly molars) and bones were found inside the Austrian Alps and the available documentation indicates that these remains were either embedded in gravel successions of MIS 3 or older or were found reworked in Late Glacial sediments or modern river beds. A notable exception is Siegsdorf in southernmost Bavaria, where a nearly complete skeleton of a large mammoth bull was excavated (Ziegler, 1994). 
1 The state of preservation of most of the other findings from inneralpin sites was poor and

2 several specimens show signs of strong mechanical abrasion.

3 In the following, the different locations and their specimens are briefly described along a W-E

4 transect across the Austrian Alps starting in the province of Vorarlberg in the west.

\section{Rhine Valley and tributaries (Vorarlberg)}

7 The Rhine paleoglacier was fed by major tributaries located in Austria (province of

8 Vorarlberg) and to a larger extent in eastern Switzerland (e.g., Keller \& Krayss, 2005a, b;

9 Preusser et al., 2011). Here we review mammoth remains from the Austrian part of this

10 system.

\section{Bregenz}

In 1989 a $30 \mathrm{~cm}$-long and $9 \mathrm{~cm}$-thick fragment of a tusk was found in the gravel pit

Hochwacht, located east of Kennelbach and north of the Bregenzer Ache (city of Bregenz;

Fig. 1). It occurred within delta foresets about $16 \mathrm{~m}$ underneath their top (Krieg, 1990). The fragment showed no signs of rounding by fluvial transportation, hence it was assumed that the tusk was initially complete and the remainder was destroyed during gravel extraction (de Graaff, 1992). The delta sediments were deposited during the LGM advance of the Rhine paleoglacier and were subsequently overridden by the ice. A previous radiocarbon date yielded an age of 23,900 $\pm 400 \mathrm{BP}$ (de Graaff, 1992; Table 1). $\mathrm{Au}$

Several findings of mammoth remains have been documented further upstream of the Bregenzer Ache in the Bregenzerwald region (Fig. 1). A first discovery was made back in $1889 \mathrm{at} \mathrm{Au}$, where two fragments of molars were found as briefly stated in an internal report

(Rechenschaftsbericht des Landesmuseum). These specimens seem to be lost (G. Friebe, pers. 
comm.). A second finding - a tusk - was made in 1911, also in Au. This specimen was discovered during construction work between the church of $\mathrm{Au}$ and Rehmen, but the documentation is again very limited (Krieg, 1989) and it is not clear where this specimen is currently stored. Finally, in 1987, a third mammoth finding was made at the same location, slightly further upstream. A large number of bones were reportedly found (Krieg, 1989), but unfortunately only one molar was preserved and is now stored at the Inatura museum in Dornbirn (inventory no. P.109).

\section{Dornbirner Ach}

A rounded and hollow tusk fragment was purchased from the estate of G. Mutschlechner (Innsbruck; G. Friebe, pers. comm.) and is now at the Inatura museum (inventory no.

P.17070). It was found in the river bed of the Dornbirner Ach (according to an old-style handwriting on the outside of this specimen), a river draining the Bregenzerwald towards the Rhine Valley (Fig. 1).

\section{Schesatobel}

Southwest of Bludenz, on the orographically left side of the Ill Valley, a thick succession of Pleistocene sediments is preserved, which form the terrace of Bürserberg and the adjacent gorge of Schesatobel (Bertle, 1999; Fig. 1), which has been a source of major debris flows in the past. This large erosional area has not only been the first site where mammoth remains were found inside the Alps (Klebelsberg, 1935, p. 594); it also yielded some of the largest and most well preserved tusks. The first recorded finding was made in 1859 (Suess, 1860; Müller, 1861). The Inatura museum stores a restored left tusk $2.2 \mathrm{~m}$ in length (inventory no. P.18773), which is most likely the first finding from Schesatobel. An even larger tusk, broken in two pieces, was found in 1860 and re-assembled (Müller, 1861). It is most likely the specimen on display in the Vorarlberg Museum in Bregenz. This left tusk is $2.86 \mathrm{~m}$ long. 1886 marked the 


\section{Inn Valley, Tyrol}

\section{Innsbruck}

discovery of another tusk fragment, which was $1 \mathrm{~m}$ long. Another fragment was found in 1907. The last one so far was found in 1997 reworked in debris-flow sediments. There are no published ages on any of the findings from Schesatobel.

Several reports of mammoth findings exist from this major inneralpine valley, between Kufstein and Innsbruck. No remains have been reported from the upper reaches of the Inn Valley nor from any of its major tributaries draining the Central Alps in the south.

In 1926 a tusk was found in a former gravel pit at Höttinger Au (Retter'sche Schottergrube), located at the northern margin of the Inn Valley within the city limits of Innsbruck (Fig. 1). The tusk was found some $5 \mathrm{~m}$ below the top of an about $25 \mathrm{~m}$-thick gravel succession, $20 \mathrm{~m}$ above the level of the nearby road. This gravel is of early Late Glacial origin and is overlain by a thin veneer of loessic sediments which locally contain archaeological remains and is known as Scherbenschotter (Klebelsberg, 1935). This tusk was likely reworked from older sediments, which are widespread along the margin of this valley forming prominent higher terraces. The specimen, which, historically speaking, was the first finding of an in-situ mammoth tusk in the province of Tyrol (Klebelsberg, 1935: 594), was 1.0-1.5 m in length and strongly fragmented (Klebelsberg, 1928). Two parts of this tusk are stored in Innsbruck: a sample consisting of small fragments is stored at the Institute of Geology, University of Innsbruck (Retter2). A restored, ca. $40 \mathrm{~cm}$-long piece of this tusk is part of the exhibition in the Zeughaus museum (Retter3).

Klebelsberg (1935, p. 521) listed two additional findings of mammoth remains in the Innsbruck area. A scapula was found in the former meadows of Wilten (southwestern part of Innsbruck) and a vertebra was identified (among human bones) in 1869 during demolition of 
the St Veit Chapel on the fromer Innsbruck hospital cemetery (now Adolf-Pichler-Platz, near the centre of Innsbruck). No further information is available about these two findings which appear to have been lost.

\section{Fritzens}

In 1985 a $40 \mathrm{~cm}$-long tusk fragment was found in the former gravel pit at Fritzens at about $570 \mathrm{~m}$ a.s.l. (Fig. 1). These gravels belong to the alluvial fan of the Bärenbach creek and form part of what is locally known in the Inn Valley as Vorterrasse, i.e. a smaller terrace in front of the larger (and higher) terrace. The latter contains glaciolacustrine and glaciofluvial sediments largely of MIS 3 age and is capped by basal till of MIS 2 age (see overview by Spötl et al., 2014a). The Vorterrasse was deposited during the early Late Glacial in an ice-marginal setting. The mammoth tusk was therefore eroded from the nearby older sediments of the higher terrace. An initial radiocarbon analysis performed in 1987 by the Hannover laboratory yielded an age of 29,600 $\pm 335 \mathrm{BP}$, but this was later discarded (Patzelt, 2014). Subsequently, a sample taken from the interior of the tusk fragment was dated using AMS to 37,350 +690/$630 \mathrm{BP}$ at the Vienna laboratory and a replicate treated using ultrafiltration yielded a very similar result (Table 1). No information was provided about the state of collagen preservation.

\section{Kramsach}

In 1941 a $52 \mathrm{~cm}$-long and approximately $20 \mathrm{~cm}$-thick fragment of the terminal part of a left tusk was found in the river bed of Brandenberger Ache at Mariatal, Kramsach (Fig. 1;

Klebelsberg, 1942). This river drains the Brandenberg Alps towards the Inn Valley. The most likely source of this tooth is Late Pleistocene gravel deposits outcropping on the orographically right river bank upstream of Mariatal (see geological map by Patzelt, 2012). The specimen is at display at the Heimatmuseum Kufstein (inventory no. Foss1A) and lacks the outer layer. No analyses were performed on this specimen due to poor preservation. 
3 The Heimatmuseum Kufstein also hosts a poorly preserved molar (inventory no. Foss2)

4 which was found in the river bed of the Inn between Wörgl and Kufstein (Fig. 1). No further

5 information is available and no analyses were performed on this specimen.

6

$7 \quad$ Kufstein

In 1932, a mammoth tusk was discovered during construction of the road from Kufstein towards Hechtsee (Heissel, 1933/34; Fig. 1). The original length of the tusk was slightly more than $2 \mathrm{~m}$, but it was heavily fragmented and embedded in fine sand which formed a lense in coarse-grained gravel. This gravel passes upsection into well-bedded glaciofluvial gravels. The succession belongs to the Late Pleistocene terrace deposits. Small fragments of this tusk are stored at the Institute of Geology, University of Innsbruck (inv. no. P6824). A larger piece of the tusk is stored at the Heimatmuseum Kufstein (inventory no. Foss1B), is about $63 \mathrm{~cm}$ long, but in poor condition.

\section{Bavarian part of the Eastern Alps}

A few reports of mammoth fossils exist from valleys in southernmost Bavaria which extend into the Eastern Alps, including the well known site Siegsdorf.

\section{Siegsdorf and Ruhpolding}

By far the most complete and best preserved mammoth skeleton was excavated between 1975 and 1986 south of Siegsdorf (Fig. 1), together with remains of Panthera leo spelaea, Canis lupus, Coelodonta antiquitatis, Megaloceros giganteus and Bos or Bison (Ziegler, 1994; Rosendahl et al., 2005). The bones were very well preserved in mud just outside (east) of the terminal moraine ridges left behind by the Chiemgau palaeoglacier. A bone of this mammoth, 
whose re-assembled skeleton is at display in the Natural History and Mammoth Museum at Siegsdorf, was dated to 45,180+1130/-990 BP (Rosendahl et al., 2005; Table 1). A bone of the cave lion was dated to $47,180+1190 /-1040 \mathrm{BP}$.

Two molars were found earlier already some $4 \mathrm{~km}$ south of Ruhpolding, a community located about $5 \mathrm{~km}$ south of Siegsdorf, inside the Northern Calcareous Alps (Fig. 1). The first molar was discoverd in 1956 in the Vordere Kraxenbach, a steep ravine leading to the Fischbach Valley. The molar was apparently eroded from thick gravel and till outcropping in the catchment of this tributary (Ebers, 1960). The second specimen was discovered soon after in the fluvial sediments of the Fischbach a few kilometres northwest of the first site (Dehm, 1982). Both teeth are stored at the Bavarian State Collection of Palaeontology and Geology in Munich.

\section{Berchtesgaden}

Remains of a mammoth were recently discovered in the Nesseltalgraben, a ravine northeast of Berchtesgaden, located inside the northern part of the Northern Calcareous Alps close to the German-Austrian border (Fig. 1). This outcrop is currently being studied and wood remains from this fossiliferous layer yielded a radiocarbon date of 43,548 \pm 1720 BP (Mayr et al., 2017).

\section{Salzach Valley (Salzburg)}

While several mammoth remains have been found north of the city of Salzburg in the former area of the Salzach outlet palaeoglacier (e.g. Tichy, 1989; Fig. 1), only one report of an inneralpine occurrence is currently known from this major valley.

\section{Bischofshofen}


1 A 1 m-long fragment of a right tusk was discovered in 1986 during construction of the motorway at Buchberg, Bischofshofen. This site is located $40 \mathrm{~km}$ upstream of the city of Salzburg (Fig. 1). The tusk was embedded in a sandy layer some $15 \mathrm{~m}$ below the surface and was heavily fragmented. A radiocarbon analysis yielded 32,400 \pm 1100 BP (Tichy, 1989; Table 1). This specimen is stored in the Museum Bischofshofen.

\section{Samples and methods}

Most samples were screened for the preservation of the whole bone nitrogen content, and collagen extraction was done on samples with sufficiently high nitrogen using the ultrafiltration method (Brown et al., 1988) with Vivaspin ${ }^{\circledR}$ filter cleaning following Bronk Ramsey et al. (2004). Samples were combusted to $\mathrm{CO}_{2}$ and processed to graphite using the zinc reduction method (Slota et al., 1987) and analysed using AMS at the ${ }^{14} \mathrm{CHRONO}$ Centre, Queen's University Belfast. Ages were calculated according to Stuiver \& Polach (1977) using the AMS measured ${ }^{13} \mathrm{C} /{ }^{12} \mathrm{C}$ which accounts for both natural and machine isotope fractionation. The reported error in the age was multiplied by 1.3 based on reproducibility of bone standards and includes long-term variability in the background. For asymmetric standard deviations the larger value is reported. Ages were calibrated using IntCal13 (Reimer et al., 2013) and the CALIB 7.10 software (Stuiver et al., 2013). Calibrated age ranges are reported at two standard deviations $(2 \sigma)$. Stable isotopes $\left(\delta^{13} \mathrm{C}\right.$ and $\left.\delta^{15} \mathrm{~N}\right), \%$ carbon and $\%$ nitrogen were measured on a Delta V Advantage with Flash elemental analyser and atomic carbon to nitrogen ratios calculated $\left(\mathrm{C} / \mathrm{N}_{\mathrm{a}}\right)$. Reproducibility for ultrafiltered bone collagen is $0.22 \%$ for $\delta^{13} \mathrm{C}$ and $0.15 \%$ for $\delta^{15} \mathrm{~N}$.

\section{Results}

Bregenz 
1 The smaller tusk fragment from Hochwacht stored at the inatura museum in Dornbirn

2 (inventory no. P.18774) yielded a very low $\mathrm{N}$ content of $0.07 \%$ (Table 1 ). No dating was

3 attempted, also because it had been treated with a glue during restoration. A piece of the

4 second, untreated specimen (probably from the interior of the tusk, labelled Hochwacht1) was

5 initially provided for this study in 2015 by L. de Graaff (via G. Friebe, inatura) and also

6 yielded a low $\mathrm{N}$ content $(0.2 \%$, Table 1$)$. Subsequently, this tusk fragment was returned to the

7 inatura museum by L. de Graaff and two additional samples taken from the outer layers

8 showed good collagen preservation (Table 1) and yielded consistent ages of 33,375 $\pm 655 \mathrm{BP}$

9 and $33,427 \pm 654 \mathrm{BP}$.

$11 \mathrm{Au}$

12 An aliquot of the molar from $\mathrm{Au}$ (P.109) failed to yield sufficient collagen. The inatura

13 museum hosts another molar fragment of a mammoth (inventory no. P.109.1) whose

14 whereabouts are not fully documented, but it likely belongs to one of the three findings from

$15 \mathrm{Au}$ (G. Friebe, pers. comm.). As the screening of a small aliquot of this molar showed good collagen preservation $\left(C / \mathrm{N}_{\mathrm{a}}=3.22\right)$, a radiocarbon dating was performed: 45,080 $\pm 3143 \mathrm{BP}$ (Table 1).

\section{Dornbirner Ach}

No dating was performed on this rounded tusk fragment (P.17070), because it was lacks stratigraphic and geographical control.

\section{Schesatobel}

24 Four aliquots were obtained from the 2.2 m-long tusk P.18773 from Schesatobel found in 1859. One yielded a very low $\mathrm{N}$ content, while the other three gave much higher values (Table 1). Their ages range from $41,246 \pm 2025 \mathrm{BP}$ to $44,206 \pm 2767 \mathrm{BP}$ (Table 1). 
1 Two small pieces obtained from the outside near the blunt tip of the $2.86 \mathrm{~m}$-long tusk at the

2 Vorarlberg Museum (sample BRE1) showed good collagen preservation as well (Table 1) and 3 the radiocarbon ages are $43,673 \pm 2574$ and 41,553 \pm 2095 (Table 1).

5 Innsbruck

6 Samples taken from the outer zone of the fragmented tusk (Retter2) yielded acceptable $\% \mathrm{~N}$ values, while a sample from the interior showed very poor preservation (Table 1). The radiocarbon dates of the first three aliquots scatter from $31,811 \pm 538 \mathrm{BP}$ to $39,918 \pm 1547 \mathrm{BP}$ (Table 1). A sample of the outer zone of the specimen from Zeughaus (Retter3) yielded a very low $\mathrm{C} / \mathrm{N}_{\mathrm{a}}$ ratio (Table 1$)$.

Kufstein

Several aliqouts of the tusk fragments from both the Institute of Geology, University of Innsbruck, and the Heimatmuseum Kufstein yielded very low values (Table 1) and no dating was performed. Bischofshofen A small fragment of the original tusk initially provided by H. Slupetzky yielded a very low $\mathrm{N}$ concentration (Table 1) and no dating was attempted. Subsequently, the outer part of the original tusk fragment, now stored at the Museum Bischofshofen, was sampled but also showed a too low $\mathrm{N}$ content (Table 1).

\section{Discussion}

With the exception of the Siegsdorf site and one of the findings from Au (which, 
1 Alps are isolated tusks or less commonly molars. According to the original and mostly scant 2 reports the state of preservation ranged from apparently complete and locally more than $2 \mathrm{~m}$

3 long tusks to heavily eroded fragments of tusks and molars. The host sediments were mostly

4 fluvioglacial gravels and sand lenses lacking organic remains or palaeosols. These clastic

5 deposits commonly show a coarsening-upward trend and are capped by basal till of LGM age.

6 Direct age control exists for these sediments is sparse, but data from underlying lacustrine

7 sediments (Spötl et al., 2013; Starnberger et al., 2013; Barrett et al., 2017) as well as

8 lithostratigraphic correlations suggest that most of these sediments are Middle Würmian in age, i.e. MIS 3, or slightly older. Siegsdorf and Nesseltalgraben are the only sites where mammoth fossils were embedded in lacustrine sediments (Rosendahl et al., 2005; Mayr et al.,

11 2017).

12 Locally, mammoth fossils were also found reworked in ice-marginal sediments of the early

13 Late Glacial (e.g., Innsbruck, Fritzens) or in modern river beds (Kramsach, Dornbirner Ach).

14 These specimens are incomplete tusks showing strong signs of mechanical erosion. An

15 exception is the Schesatobel site, where several and rather well preserved mammoth tusks were found over the course of some 150 years. None of them, however, were found in-situ, but reworked in modern debris-flow deposits.

Quality of the radiocarbon dates According to van Klinken (1999) and Brock et al. (2012), a minimum content of $0.7 \% \mathrm{~N}$ is required for a reliable radiocarbon measurement of the collagen fraction of bones. Recommended values for $\mathrm{C} / \mathrm{N}_{\mathrm{a}}$ ratios of bulk bone or tooth range from 2.9 to 3.5 (van Klinken, 1999; Bronk Ramsey et al., 2004; van der Plicht \& Palstra, 2016) with collagen yields of $1 \%$ or greater (van Klinken, 1999). 
1 Screening showed that the state of preservation varies significantly within individual 2 specimens. Only those samples yielding at least $1 \% \mathrm{~N}$ were dated, corresponding to $\mathrm{C} / \mathrm{N}_{\mathrm{a}}$ 3 ratios of 3.2 or higher and collagen yields of $1 \%$ or more (Table 1 ).

4 We attempted to analyse specimens at least in duplicate to obtain robust chronological 5 information. Table 1 shows that data from the specimens at Bregenz (Hochwacht) and Schesatobel have good internal agreement, while the tusk fragment from Innsbruck yields a large intra-sample variability, despite good $\mathrm{C} / \mathrm{N}_{\mathrm{a}}$ ratios.

The range of the new ages is consistent with previously published data of the mammoth remains from Fritzens in the lower Inn Valley (Patzelt, 2014) and Siegsdorf in Bavaria (Rosendahl et al., 2005) and show that mammoths were present inside the Eastern Alps during the first part of MIS 3 and likely before that (Fig. 2). Our data do not support published radiocarbon data from two localities, Bischofshofen and Bregenz. The tusk fragment found at Buchberg near Bischofshofen was screened twice and the $\% \mathrm{~N}$ values were very low, indicating insufficient collagen preservation. Hence, the published date (Tichy, 1989; which did not include data on $\% \mathrm{~N}$, the $\mathrm{C} / \mathrm{N}_{\mathrm{a}}$ ratio, or collagen yield) should be viewed with caution. The well preserved outer zone (cementum) of the tusk fragment from Bregenz yielded two consistent ages which show that this individual lived between 36.1 and 39.2 cal ka BP (2 sigma), i.e. significantly older than the originally published data (23,900 $\pm 400 \mathrm{BP}$, de Graaff, 1992), corresponding to 27.4-28.7 cal BP (2 sigma). We note that two initial subsamples taken from the interior of this tusk showed poor collagen preservation (Table 1) pointing to intrasample differences in the degree of collagen degradation. We therefore question the validity of the radiocarbon age reported by de Graaff (1992).

24 The ages from the Austrian Alps compare favorably with the radiocarbon age constraints from Niederweningen, the best studied mammoth site in northern Switzerland. There, 
mammoth bones yielded an age of 45,870 \pm 1080 BP (using ultrafiltration: $45,720 \pm 710 \mathrm{BP}$ ), corresponding to a calibrated age of >47.0-47.6 cal ka BP (Hajdas et al., 2007, 2009; Fig. 2).

\section{Mammoths and palaeoclimate in the Alps}

Despite a limited database - reflecting the small number of mammoth fossils made over a period of more than one and a half centuries - this study underscores that mammoths, although steppe animals, migrated deeply into the Eastern Alps during the last glacial period. This concept of inneralpine mammoths was already proposed by Suess (1860) in a brief report about the Schesatobel findings. Later Ebers (1960) developed this idea a bit further. In fact, she proposed that mammoths invaded the northern mountain chains of the Alps as the ice gradually retreated at the end of the LGM. It is now clear that these animals were present significantly earlier and none of the mammoth fossils dates to the Late Glacial, although mammoths became extinct in Europe only during the Bølling interstadial (Stuart, 2005). Most of the inneralpine mammoth findings date to the first part of MIS 3. The host sediments are mostly coarse-grained (glacio)fluvial deposits largely devoid of organic remains.

Available proxy data from lacustrine sediments associated with these clastic sediments indicate a tundra vegetation. During interstadials scattered tree stands are recorded by pollen data from inneralpine sites (Starnberger et al., 2013, Barrett et al., 2018). Only during the most pronounced interstadial of MIS 3, corresponding to Greenland Interstadial 14 (54.2-49.6 ka, and possibly Interstadial 12, lasting from 46.9 to $44.3 \mathrm{ka}$; Rasmussen et al., 2014), did boreal spruce forests exist locally along the north(western) alpine foreland (e.g., Niederweningen - Drescher-Schneider, 2007). Stable isotope data of mammoth molar enamel from this site suggest mean air temperatures about $4^{\circ} \mathrm{C}$ lower than today (Tütken et al., 2007). Speleothems from caves in the Eastern Alps show strong evidence of pronounced stadialinterstadial climate swings, mimicking the Dansgaard-Oeschger pattern known from Greenland ice cores (Boch et al., 2011; Moseley et al., 2014). Glaciers were likely

$$
-16 \text { - }
$$


significantly larger than during the Little Ice Age maximum (1850 AD) even during major interstadials of MIS 3 (e.g., Spötl et al., 2006). This is consistent with semi-continuous loess deposition in the alpine foreland, e.g. along the Danube corridor and the presence of tundra gley soils indicating deep frost or permafrost conditions during stadials (Thiel et al., 2011;

Nigst et al., 2014).

Only the mammoth findings from Bregenz (and possibly the one from Innsbruck) date to the second half of MIS 3. This is consistent with the progressive deterioration of the climate after about $40 \mathrm{ka}$ and in particular after about $30 \mathrm{ka}$. The interval 32-30 ka marked the first major advance of alpine glaciers as recorded by the onset of strong glaciofluvial gravel aggradation in the central Inn Valley (Spötl et al., 2013), the Rhine Valley (Keller \& Krayss, 2005a, b; Preusser et al., 2011) and in the foreland of the Tagliamento paleoglacier (Monegato et al., 2007, 2017). Loess accumulation in the foreland of the Salzach palaeoglacier commenced ca. 30 ka ago (Starnberger et al., 2011) and the bulk of the loess in the central Danube valley was deposited after ca. $31 \mathrm{ka}$ (Lomax et al., 2014). At the same time cave bears disappeared from the low-lying caves in the Alps (Spötl et al., 2014b; Rabeder \& Frischauf, 2016).

There is a striking difference in the distribution of mammoth fossils between the Eastern Alps of Austria and the Western Alps of Switzerland. There is no evidence of mammoth fossils in large valleys of the Western Alps, e.g. the Aare or Rhone Valley. Interestingly, there are also no reports of such fossils from the Swiss part of the inneralpine Rhine Valley, but several from the area of its outlet glacier lobe between St. Gallen and Schaffhausen (e.g., Furrer, 2005). The lack of mammoth remains inside the Western Alps is probably related to the fact that sediments of MIS 3 age are much more abundant than in valleys of the Eastern Alps, where they form prominent terraces (e.g., in the Inn and Enns Valleys). This in turn may have been related to the size (and hence flow speed and erosive capacity) of westalpine glaciers which were larger than their eastalpine counterparts, reflecting their higher accumulation areas and the less continental climate in Switzerland as compared to the Eastern Alps. 
1 Of particular stratigraphic interest is the Bregenz (Hochwacht) site near Lake Constance,

2 because the mammoth tusk occurred within proglacial gravel and its radiocarbon date

3 provides a (now revised) maximum age constraint for the advance of the Rhine palaeoglacier

4 beyond the northern margin of the Alps.

\section{Conclusions}

7 The results of this study confirm earlier reports that the woolly mammoth entered the valleys of the Austrian Alps up to several tens of kilometres behind the alpine front prior to the LGM. First radiocarbon data from the important Schesatobel site in Vorarlberg are reported, which was not only the first mammoth discovery inside the Alps (in 1859) but also the richest suite of well preserved tusks. The radiocarbon dates indicate that this fauna dates to the first half of

12 MIS 3

13 We also revised the age of the mammoth tusk from Hochwacht near Bregenz, whose

14 previously reported calibrated age was about $10 \mathrm{ka}$ too young. The new dates are more consistent with other alpine mammoth findings and places constraints on the timing of the advance of the Rhine Glaciers beyond the northalpine front. Re-analysing the only mammoth remain ever found in the inneralpine Salzach Valley showed very poor collagen preservation, calling into question the validity of the previously reported radiocarbon age (Tichy, 1989). Summarizing, there is now compelling evidence that major inneralpine valleys were ice-free during the first half the MIS 3, allowing mammoths to migrate deeply into the Eastern Alps.

Radiocarbon dating of such old samples is associated with significant uncertainties precluding the assignment of the samples to individual interstadials or stadials. The lack of mammoth younger than about $36 \mathrm{ka}$ is attributed to the progressively colder and drier climate leading to the advance of the mountain glaciers into the large valleys and the final buildup of the icestream network during the LGM. 
1 Finally, we compiled a list and a map of all Austrian mammoth findings, stored in Austrian museums and collections or mentioned in publications, which illustrate the high density of mammoth remains along the Danube River in Upper and Lower Austria and along the lower Mur Valley in Styria, i.e. outside the formerly glaciated area.

\section{Acknowledgements}

We are grateful to the following colleagues for providing access to and information about mammoth specimens in various collections in Austria: Georg Friebe (Inatura, Dornbirn), Gerhard Tarmann (Ferdinandeum, Innsbruck), Gerhard Grabher (Vorarlberg Museum, Bregenz), Christoph Plawenn (Museum Bischofshofen), Leo De Graaff, Anna Bieniok and Robert Lindner (Haus der Natur, Salzburg), Heinz Slupetzky, Martin Gross (Universalmuseum Joanneum, Graz), Björn Berning (Oberösterreichisches Landesmuseum, Linz), Harald Steininger (Museum Niederösterreich, St. Pölten), Johannes Tuzar (Krahuletz Museum, Eggenburg), Claudia Dojen (Landesmuseum Kärnten, Klagenfurt), Maria Tschach (Landesmuseum Burgenland, Eisenstadt), Karl Rauscher (Institut für Paläontologie Universität Wien), Irene Zorn (Geologische Bundesanstalt, Vienna), Ernst Lauermann (Urgeschichtemuseum MAMUZ, Mistelbach) and Konstantina Saliari (NHMW, providing data from district museums in Vienna). Finally, we acknowledge the careful reviews by the journal referees.

\section{References}

Barnes, I., Shapiro, B., Lister, A., Kuznetsova, T., Sher, A., Guthrie, D., Thomas, M.G., 2007. Genetic structure and extinction of the Woolly Mammoth, Mammuthus primigenius. Curr. Biol. 17, 1072-1075. 
Barrett, S., Drescher-Schneider, R., Starnberger, R., Spötl, C., 2018. Insights into the vegetation and climate of the Inn Valley (Eastern Alps, Austria) during the last glacial cycle: pollen analysis of the Baumkirchen palaeolake sequence. Quat. Res. (in press).

Barrett, S., Starnberger, R., Tjallingii, R., Brauer, A., Spötl, C., 2017. The sedimentary history of the inneralpine Inn Valley (Austria): extending the Baumkirchen type section further back in time withn new drilling. J. Quaternary Sci. 32, 63-79.

Bertle, H., 1999. Schesa-Bruchkessel, Bürserberg - Vorarlberg: Mehrphasiger Murschuttfächeraufbau, Ausräumungsgeschichte, Sanierung durch Rückböschung. Mitt. Ges. Geol.- Bergbaustud. Österr. 42, 139-179.

Boch, R., Cheng, H., Spötl, C., Edwards, R.L. Wang, X., Häuselmann, P., 2011. NALPS: a precisely dated European climate record 120-60 ka. Climate Past 7, 1247-1259.

Boeskorov, G.G., Mashchenkob, E.N., Plotnikovc, V.V., Shchelchkovad, M.V., Protopopovc, A.V., Solomonov, N.G., 2016. Adaptation of the woolly mammoth Mammuthus primigenius (Blumenbach, 1799) to habitat conditions in the glacial period. Contemporary Problems in Ecol. 9, 544-553.

Braun, I.M., Palombo, M.R., 2012. Mammuthus primigenius in the cave and portable art: An overview with a short account on the elephant fossil record in Southern Europe during the last glacial. Quat. Int. 276-277, 61-76.

Brock, F., Wood, R., Higham, T.F.G., Ditchfield, P., Bayliss, A., Bronk Ramsey, C., 2012. Reliability of nitrogen content $(\% \mathrm{~N})$ and carbon:nitrogen atomic ratios $(\mathrm{C}: \mathrm{N})$ as indicators of collagen preservation suitable for radiocarbon dating. Radiocarbon 54, 879-886.

Bronk Ramsey, C., Higham, T., Bowles, A., Hedges, R., 2004. Improvements to the pretreatment of bone at Oxford. Radiocarbon 46, 155-163.

Brown, T.A., Nelson, D.E., Vogel, J.S., Southon, J.R., 1988. Improved collagen extraction by modified Longin method. Radiocarbon 30, 171-177. 
Cooper, A., Turney, C., Hughen, K.A., Brook, B.W., McDonald, H.G., Bradshaw, C.J.A.,

2015. Abrupt warming events drove Late Pleistocene Holarctic megafaunal turnover. Science $349,602-606$.

De Graaff, L.W.S., 1992. Zur Altersbestimmung eines Mammut-Stoßzahns (Kiesgrube Hochwacht) und ihre Bedeutung für die morphostratigraphische Einstufung der Quartärablagerungen zwischen Bregenz und Lagen. Schriften Vorarlberger Landesmus. A5, 23-28

Dehm, R., 1982. Jungpleistozäne Elefanten-Funde am südbayerischen Alpenrand. Mitt. Bayer. Staatssammlung Paläont. Hist. Geol. 22, 113-115.

Döppes, D., Rabeder, G., 1997. Pliozäne und pleistozäne Faunen Österreichs. Mitt. Komm. Quartärforsch. Österr. Akad. Wiss. 10, 1-411.

Drescher-Schneider, R., 2007. Palaeobotanical investigations at the mammoth site of Niederweningen (Kanton Zürich), Switzerland. Quat. Int. 164-165, 113-129.

Ebers, E., 1960. Mammute in den Alpen. Abh. Dt. Akad. Wiss. Berlin., K1. III, 1960/1, 267271.

Furrer, H., 2014. Mammutfundorte in der Schweiz. C H. Furrer (Mammutmuseum Niederweningen). http://www.mammutmuseum.ch/index.php/mammutfunde-106.html. Furrer, H., 2005. Niederweningen, die bedeutendste Mammutfundstelle der Schweiz : Neufunde und eigenes Mammutmuseum. Bull. angew. Geol. 10: 61-69.

Geologische Bundesanstalt, 2013. Der Alpenraum zum Höhepunkt der letzten Eiszeit. - Geol. Survey of Austria (Vienna), https://opac.geologie.ac.at/wwwopacx/wwwopac.ashx?command=getcontent\&server=i $\underline{\text { mages \&value }=\text { Poster Alpenraum } \% 20 \text { Eiszeit opt.pdf }}$

Gleirscher, P., Pacher, M., 2005. Griffen und die Altsteinzeit im Südostalpenraum. Rudolfinum. Jahrb. Landesmus. Kärnten 2004, 65-107. 
Göhlich, U.B., 2015. Als Mammuts noch durch Niederösterreich streiften. Faszinierende Großsäuger der Vorzeit. Naturschutzbunt 2015, 6.

Hajdas, I., Michczynski, A., Bonani, G., Wacker, L., Furrer, H., 2009. Dating bones near the limit of the radiocarbon dating method: study case mammoth from Niederweningen, $\mathrm{ZH}$ Switzerland. Radiocarbon 51, 675-680.

Hajdas, I., Bonani, G., Furrer, H., Mäder, A., Schoch, W., 2007. Radiocarbon chronology of the mammoth site at Niederweningen, Switzerland: Results from dating bones, teeth, wood, and peat. Quat. Int. 164-165, 98-105.

Heiri, O., Koinig, K.A., Spötl, C., Barrett, S., Brauer, A., Drescher-Schneider, R., Gaar, D., Ivy-Ochs, S., Kerschner, H., Luetscher, M., Moran, A., Nicolussi, K., Preusser, F., Schmidt, R., Schoeneich, P., Schwörer, C., Sprafke, T., Terhorst, B., Tinner, W., 2014. Palaeoclimate records 60-8 ka in the Austrian and Swiss Alps and their forelands. Quat. Sci. Rev. 106, 186-205.

Heissel, W., 1933/34. Fund eines Mammutzahns bei Kufstein (Tirol). Z. Gletscherk. 21, 196197.

Ivy-Ochs, S., Kerschner, H., Reuther, A., Preusser, F., Heine, K., Maisch, M., Kubik, P.W., Schlüchter, C., 2008. Chronology of the last glacial cycle in the European Alps. J. of Quat. Sci. 23, 559-573.

Kahlke, R.-D., 2015. The maximum geographic extension of Late Pleistocene Mammuthus primigenius (Proboscidea, Mammalia) and its limiting factors. Quat. Int. 379, 147-154.

Keller, O., Krayss, E., 2005a. Der Rhein-Linth-Gletscher im letzten Hochglazial. 1. Teil: Einleitung; Aufbau und Abschmelzen des Rhein-Linth-Gletschers im Oberen Würm. Vierteljahrsschrift Naturforsch. Ges. Zürich 150,: 19-32.

Keller, O., Krayss, E., 2005b. Der Rhein-Linth-Gletscher im letzten Hochglazial. 2. Teil: Datierung und Modelle der Rhein-Linth-Vergletscherung. Klima-Rekonstruktionen. Vierteljahrsschrift Naturforsch. Ges. Zürich 150, 69-85. 
Klebelsberg, R. v., 1942. Ein Mammut-Fund im tirolischen Inntal. Z. Gletscherk. 28, 188.

Klebelsberg, R. v., 1935. Geologie von Tirol. Berlin (Borntraeger).

Klebelsberg, R. v., 1928. Ein Mammutzahn-Fund bei Innsbruck. Z. Gletscherk. 16, 261-262.

4 Krieg, W., 1990. Das Mammut in Vorarlbergs Eiszeit. Vorarlberger Oberland 1990/3, 121123.

Krieg, W., 1989. Der dritte Mammutfund in Vorarlberg. Jahrb. Vorarlberger Landesmuseumsver. 1989, 15-18.

Kuzmin, Y.V., 2010. Extinction of the woolly mammoth (Mammuthus primigenius) and woolly rhinoceros (Coelodonta antiquitatis) in Eurasia: Review of chronological and environmental issues. Boreas 39, 247-261.

Lister, A.M., Bahn P.G., 2015. Mammoths. Giants of the Ice Age. Chartwell Books.

Lister, A.M., Sher, A.V., 2015. Evolution and dispersal of mammoths across the Northern Hemisphere. Science 350, 805-809.

Lister, A.M., Sher, A.V., 2001. The origin and volution and of the woolly mammoth. Science 294, 1094-1097.

Lomax, J., Fuchs, M., Preusser, F., Fiebig, M., 2014. Luminescence based loess chronostratigraphy of the Upper Palaeolithic site Krems-Wachtberg, Austria. Quat. Int. 351, 88-97.

Markova, A.K., Puzachenko, A.Y., van der Plicht, J., van Kolfschoten, T., Ponomarev, D.V., Kotlyakov, V.M., 2010. New data on the dynamics of the mammoth Mammuthus primigenius distribution in Europe in the second half of the Late Pleistocene-Holocene. Doklady Earth Sci. 431, 479-483.

Mayr, C., Brandlmeier, B., Diersche, V., Stojakowits, P., Kirscher, U., Matzke-Karasz, R., Bachtadse, V., Eigler, M., Haas, U., Lempe, B., Reimer, P.J., Spötl, C., 2017. Nesseltalgraben, a new reference section of the last glacial period in southern Germany. J. Paleolimnol. 58, 213-229. 
Miller, W. and 21 co-authors, 2008. Sequencing the nuclear genome of the extinct woolly mammoth. Nature 456, 387-390.

Monegato, G., Scardia, G., Hajdas, I., Rizzini, F., Piccin, A., 2017. The Alpine LGM in the boreal ice-sheets game. Sci. Rep. 7, 2078, DOI:10.1038/s41598-017-02148-7.

Monegato, G., Ravazzi, C., Donegana, M., Pini, R., Calderoni, G., Wick, L., 2007. Evidence of a two-fold glacial advance during the last glacial maximum in the Tagliamento end moraine system (eastern Alps). Quat. Res.h 68, 284-302.

Moseley, G.E., Spötl, C., Cheng, H., Svennson, A., Brandstätter, S., Edwards, R.L., 2014. Multi-speleothem record reveals tightly coupled climate between Central Europe and Greenland during MIS 3. Geology 42, 1043-1046.

Müller, T.W., 1861. Bericht über den im Museum befindlichen, im Schesa=Tobel aufgefundenen Mammuthstoßzahn. Dritter Rechenschafts-Bericht des Ausschusses des Vorarlberger Museums-Vereins in Bregenz 1861, 29-37.

Mussi, M., Villa, P., 2008. Single carcass of Mammuthus primigenius with lithic artifacts in the Upper Pleistocene of northern Italy. J. Archaeol. Sci. 35, 2606-2613.

Nigst, P.R., Haesaerts, P., Damblon, F., Frank-Fellner, C., Mallol, C., Viola, B., Götzinger, M., Niven, L., Trnka, G., Hublin, J.-J., 2014. Early modern human settlement of Europe north of the Alps occurred 43,500 years ago in a cold steppe-type environment. PNAS 111, 14394-14399.

North Greenland Ice Core Project members, 2004. High-resolution record of Northern Hemisphere climate extending into the last interglacial period. Nature 431, 147-151.

Palkopoulou, E., Dalén, L., Lister, A.M., Vartanyan, S., Sablin, M., Sher, A., Edmark, V.N., Brandström, M.D., Germonpré, M., Barnes, I., Thomas, J.A., 2013: Holarctic genetic structure and range dynamics in the woolly mammoth. Proc. Royal Soc. B 280, 20131910, http://dx.doi.org/10.1098/rspb.2013.1910. 
Patzelt, G., 2014. Das Mammutzahn-Bruchstück von Fritzens (Inntal, Tirol) und seine Stellung in der Chronologie des ostalpinen Spätpleistozäns. Jahrb. Geol. Bundesanst. $154,71-82$.

Patzelt, G., 2012. Die Bergstürze vom Pletzachkogel, Kramsach, Tirol. Jahrb. Geol. Bundesanst. 152, 25-38.

Preusser, F., Graf, H.R., Keller, O., Krayss, E., Schlüchter, C., 2011. Quaternary glaciation history of northern Switzerland. Quat. Sci. J. 60, 282-305.

Puzachenko, Y.Y., Markova, A.K., Kosintsev, P.A., van Kolfschoten, T., van der Plicht, J., Kuznetsova, T.V., Tikhonov, A.N., Ponomarev, D.V., Kuitems, K., Bachura, O.P., 2017. The Eurasian mammoth distribution during the second half of the Late Pleistocene and the Holocene: Regional aspects. Quat. Int. 445, 71-88.

Rabeder, G., Frischauf, C., 2016. Fossile Bären in Höhlen. In: Höhlen und Karst in Österreich (Ed. by C. Spötl, L. Plan, E. Christian), Oberösterreichisches Landesmuseum, 183-198.

Rasmussen, S.U., Bigler, M., Blockley, S.P., Blunier, T., Buchardt, S.L., Clausen, H.B., Cvijanovic, I., Dahl-Jensen, D., Johnsen, S.J., Fischer, H., Gkinis, V., Guillevic, M., Hoek. W.Z., Lowe, J.J., Pedro, J.P., Popp, T., Seierstad, I.K., Steffensen, J.P., Svensson, A.M., Vallelonga, P., Vinther, B.M., Walker, M.J.C., Wheatley, J.J., Winstrup, M., 2014. A stratigraphic framework for abrupt climatic changes during the Last Glacial period based on three synchronized Greenland ice-corerecords: refining and extending the INTIMATE event stratigraphy. Quat. Sci. Rev. 106, 14-28.

Reimer, P.J., Bard, E., Bayliss, A., Beck, J.W., Blackwell, P.G., Bronk Ramsey, C., Buck, C.E., Edwards, R.L., Friedrich, M., Grootes, P.M., Guilderson, T.P., Haflidason, H., Hajdas, I., Hatté, C., Heaton, T.J., Hoffman, D.L., Hogg, A.G., Hughen, K.A., Kaiser, K.F., Kromer, B., Manning, S.W., Niu, M., Reimer, R.W., Richards, D.A., Scott, M., Southon, J.R., Staff, RA, Turney, C.S.M., van der Plicht, J., 2013. IntCal13 and 
Marine13 radiocarbon age calibration curves 0-50,000 years cal BP. Radiocarbon 55, 1869-1887.

Rosendahl, W., Darga, R., Burger, J., 2005. Die pleistozäne Großsäugerfauna von Siegsdorf (Süddeutschland) - neue Untersuchungen. Mitt. Komm. Quartärforsch. Österr. Akad. Wiss. 14, 153-160.

Scholz, H., 2016. Bau und Werden der Allgäuer Landschaft. $3^{\text {rd }}$ ed., Stuttgart (Schweizerbart). Scholz, O., 1979. Elefantenreste aus pleistozänen Ablagerungen in und um Kempten, ausgestellt im Museum Zumsteinhaus. Mitt. Naturwiss. Arbeitskreis Kempten 23, 1924.

Schwartz-Narbonne, R., Longstaffe, F.J., Metcalfe, J.Z., Zazula, G., 2015. Solving the woolly mammoth conundrum: amino acid ${ }^{15} \mathrm{~N}$-enrichment suggests a distinct forage or habitat. Sci. Rep. 5:09791, DOI: 10.1038/srep09791.

Slota, P.J., Jull, A.J.T., Linick, T.W., Toolin, L.J., 1987. Preparation of small samples for C14 accelerator targets by catalytic reduction of Co. Radiocarbon 29, 303-306.

Spötl, C., Starnberger, R., Barrett, S., 2014a. The Quaternary of Baumkirchen (central Inn Valley, Tyrol) and its surroundings. - In: From the foreland to the Central Alps. Field trips to selected sites of Quaternary research in the Tyrolean and Bavarian Alps (ed. by H. Kerschner, K. Krainer, C. Spötl), 68-80, Berlin (Geozon).

Spötl, C., Reimer, P.J., Rabeder, G., Scholz, D., 2014b. Presence of cave bears in western Austria before the onset of the Last Glacial Maximum: new radiocarbon dates and palaeoclimatic considerations. J. Quat. Sci. 29, 760-766.

Spötl, C., Mangini, A., Richards, D.A., 2006. Chronology and paleoenvironment of Marine Isotope Stage 3 from two high-elevation speleothems, Austrian Alps. Quat. Sci. Revi. $25,1127-1136$. 
Spötl, C., Reimer, P.J., Starnberger, R., Reimer, R., 2013. A new radiocarbon chronology of Baumkirchen, stratotype for the onset of the Upper Würmian in the Alps. J. Quat. Sci. $28,552-558$

Starnberger, R., Drescher-Schneider, R., Reitner, J., Rodnight, H., Reimer, P.J., Spötl, C., 2013. Late Pleistocene climate change and landscape dynamics in the Eastern Alps: the inner-alpine Unterangerberg record (Austria). Quat. Sci. Rev. 68, 17-42.

Starnberger, R., Rodnight, H., Spötl, C., 2011. Chronology of the Last Glacial Maximum in the Salzach Palaeoglacier Area (Eastern Alps). J. Quat. Sci. 26, 502-510.

Stuart, A.J., 2005. The extinction of wooly mammoth (Mammuthus primigenius) and straighttusked elephant (Palaeoloxodon antiquus) in Europe. Quat. Int. 126-128, 171-177.

Stuart, A.J., Kosintsev, P.A., Higham, T.F.G., Lister, A.M., 2004. Pleistocene to Holocene extinction dynamics in giant deer and woolly mammoth. Nature 431, 684-689.

Stuiver, M., Polach, H.A., 1977. Reporting of C-14 data - Discussion. Radiocarbon 19, 355363.

Stuiver, M., Reimer, P.J., Reimer, R.W., 2013. CALIB 7.10. (WWW program and documentation). http://calib.qub.ac.uk/calib.

Suess, E., 1860. Auffindung des Stosszahnes eines Elephanten. Verh. k. k. geol. Reichsanst. $1860,84-85$

Svensson, A., Andersen, K.K., Bigler, M., Clausen, H.B., Dahl-Jensen, D., Davies, S.M., Johnsen, S.J., Muscheler, R., Parrenin, F., Rasmussen, S.O., Röthlisberger, R., Seierstad, I., Steffensen, J.P., Vinther, B.M., 2008. A 60000 year Greenland stratigraphic ice core chronology. Climate Past 4, 47-57.

Terhorst, B., Thiel, C., Peticzka, R., Sprafke, T., Frechen, M., Fladerer, F.A., Roetzel, R., Neugebauer-Maresch, C., 2011. Casting new light on the chronology of the loess/paleosol sequences in Lower Austria. E\&G Quat. Sci. J. 60, 270-277. 
Thiel, C., Terhorst, B., Jaburová, I., Baylaert, J.-P., Murray, A.S., Fladerer, F.A., Damm, B.,

Frechen, M., Ottner, F., 2011. Sedimentation and erosion processes in Middle to Late Pleistocene sequences exposed in the brickyard of Langenlois/Lower Austria. Geomorphology 135, 295-307.

Tichy, G., 1989. Neue Mammutfunde aus Salzburg und Oberösterreich. Oberösterr. Geonachrichten 4, 1-31.

Tütken, T., Furrrer, H., Vennemann, T.W., 2007. Stable isotope compositions of mammoth teeth from Niederweningen, Switzerland: Implications for the Late Pleistocene climate, environment, and diet. Quat. Int., 164-165, 139-150.

Ukkonen, P., Aaris-Sørensen, K., Arppe, L., Clark, P.U., Daugnora, L., Lister, A.M., Lougas, L., Seppä, H., Sommer, R.S., Stuart, A.J., Wojtal, P., Zupins, I., 2011. Woolly mammoth (Mammuthus primigenius Blum.) and its environment in northern Europe during the last glaciation. Quat. Sci. Rev., 30, 693-712.

van der Plicht. J., Palstra. S.W.L., 2016. Radiocarbon and mammoth bones: what's in a date. Quat. Int. 406, 246-51.

van Klinken, G.J., 1999. Bone collagen quality indicators for palaeodietry and radiocarbon measurements. J. Archaeol. Sci. 26, 687-695.

Willerslev, E. and 50 co-authors, 2014. Fifty thousand years of Arctic vegetation and megafaunal diet. Nature 506, 47-51.

Ziegler, R., 1994. Das Mammut (Mammuthus primigenius Blumenbach) von Siegsdorf bei Traunstein (Bayern) und seine Begleitfauna. Münchner Geowiss. Abh. 26, 49-80. 


\section{TABLES AND FIGURE CAPTIONS}

Table 1: Mammoth specimens examined and mentioned in this study and their analytical data.

Supplementary Table 1: List of mammoth sites found in Austria, arranged according to the federal provinces. Based on specimens stored in 20 scientific collections in Austria.

Fig. 1: Relief map of Austria showing the occurrence of mammoth remains in relation to the maximum extent of the alpine ice stream network (nunataks are omitted for clarity - source: Geologische Bundesanstalt, 2013). Locations mentioned in the text are labelled (DA..Dornbirner Ach, BH..Bischofshofen, BE..Berchtesgaden, RP..Ruhpolding). Based on the list of Austrian mammoth sites (see electronic supplement) and Scholz $(1979,2016)$ for some Bavarian sites close to the Alps. Yellow lines are national borders.

Fig. 2: Distribution of calibrated ages (2 sigma ranges) of mammoth remains inside the Eastern Alps plotted on the Greenland ice-core record as a Northern Hemisphere paleoclimate template (GICC05, North Greenland Ice Core Project members, 2004; Svensson et al., 2008) and the NALPS speleothem record from the northern Alps (Moseley et al., 2014; different colours represent different stalagmites). Greenland interstadials are numbered following Rasmussen et al. (2014). Also plotted are published radiocarbon data from Siegsdorf and Berchtesgaden (southernmost Bavaria) and Fritzens (see Table 1 for references) as well as from the best characterised mammoth site in northern Switzerland, Niederweningen (Hajdas et al., 2009). Ages whose upper limit exceeds the current limit of radiocarbon calibration are indicated by an asterisk. 